\title{
DISTRIBUTION PATTERNS OF CHAETOGNATA, POLYCHAETA, PTEROPODA AND SALPIDAE OFF SOUTH GEORGIA AND SOUTH ORKNEY ISLANDS
}

\author{
Alina María Crelier ${ }^{1}$, José Roberto Dadon ${ }^{2}$,Hernán G. Isbert-Perlender ${ }^{3}$, \\ Daniel Eduardo Nahabedian ${ }^{I}$ and María Cristina Daponte ${ }^{I^{*}}$ \\ ${ }^{1}$ Facultad de Ciencias Exactas y Naturales - Universidad de Buenos Aires \\ Departamento de Biodiversidad y Biología Experimental \\ (Pabellón II, Ciudad Universitaria, EHA1428 Buenos Aires, Argentina) \\ ${ }^{2}$ Facultad de Ciencias Exactas y Naturales - Universidad de Buenos Aires \\ Departamento de Ecología, Genética y Evolución \\ (Pabellón II, Ciudad Universitaria, EHA1428 Buenos Aires, Argentina)
}

${ }^{3}$ Servicio Naval de Investigación y Desarrollo (SENID) - Armada Argentina (Av. del Libertador 327, B1638 BEC Vicente López, Buenos Aires, Argentina)

*daponte@bg.fcen.uba.ar

\begin{abstract}
A B S T R A C T
The distribution pattern, frequency and density (ind./1000 m) of different mesozooplankton species from the South Georgia Islands, South Orkney Islands and the Weddell-Scotia Confluence were analyzed using data obtained in 1994. The maximum densities of the species found were: Eukrohnia hamata (5330), Sagitta gazellae (1052), Clione limacina antarctica (450), Spongiobranchaea australis (375), Clio sulcata (100),

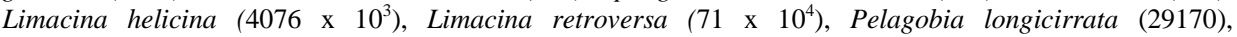
Rhynchonereella bongraini (117), Tomopteris carpenterii (26), Tomopteris planktonis (498), Tomopteris septentrionales (498) and Salpa thompsoni (189). Species density and frequency decreased from South Georgia to the South Orkney Islands, recording intermediate values at the Weddell-Scotia Confluence. Species density in the South Orkney area seemed to be limited by variations in temperature and salinity. The southern area around South Georgia showed the highest density of species, probably due to the influence of the Southern Front of the Antarctic Circumpolar Current. The presence of species characteristic of subAntarctic waters such as L. retroversa in the Confluence area could be related to the southward movements of eddies that originate in the Polar Front.
\end{abstract}

\section{RESUMO}

Foram analisados os padrões de distribuição, freqüência e densidade (ind. $1000 \mathrm{~m}$ ) de diferentes espécies de mesozooplâncton encontradas em torno das ilhas Georgias e Orcadas del Sur no verão de 1994. As densidades máximas apresentadas pelas espécies principais foram: Eukrohnia hamata (5330), Sagitta gazellae (1052), Clione limacina antarctica (450), Spongiobranchaea australis (375), Clio sulcata (100), Limacina helicina $\left(4076 \times 10^{3}\right)$, Limacina retroversa $\left(71 \times 10^{4}\right)$; Pelagobia longicirrata (29170), Rhynchonereella bongraini (117), Tomopteris carpenterii (26), Tomopteris planktonis (498), Tomopteris septentrionales (498) y Salpa thompsoni (189). A densidade e frequiência das espécies diminuíram das ilhas Georgias em direção às Orcadas, registrando-se valores médios na confluência Weddell-Scotia. A densidade de espécies nas Orcadas parece estar limitada pelas variações na temperatura e salinidade. Nas Georgias, a área sul mostrou a maior densidade de espécies, e isto poderia ser devido a influência da Frente sul da Corrente Circumpolar Antártica. A presença de espécies características de águas sub-antárticas (Ex. L. helicina) na confluência Weddel-Scotia poderia estar relacionada com o movimento dos vórtices da Frente Polar em direção Sul.

Descriptors: Mesozooplankton distribution, Chaetognaths, Polychaetes, Pteropods, Salps, Southern Ocean, Weddell-Scotia Confluence.

Descritores:_Distribuição do mesozooplâncton, Chaetognatas, Poliquetas, Pterópodes, Salpas, Oceano Antártico, Confluência Weddell-Scotia.

\section{INTRODUCTION}

Many studies have highlighted the high biological productivity around the South Georgia Islands (WARD et al., 2002, 2003; GILPIN et al., 2002; ATKINSON et al., 2001; WHITEHOUSE et al., 1996; ATKINSON; PECK, 1988) and, to a lesser extent, the South Orkney Islands (SIGLEO et al.,
2000). Research has been focused mainly on euphausiids (particularly Euphausia superba) and copepods, (e.g. ATKINSON, 1998; VORONINA, 1998; FRANSZ; GONZALEZ, 1997), while other components of the mesozooplankton have scarcely been investigated. However, they may play a major role in our understanding of the productivity of the Southern Ocean. 
Pteropods (thecosomes and gymnosomes) are ubiquitous components of zooplankton communities, with some species being extremely abundant in different areas. The genus Limacina is often reported as one of the components of mesozooplankton in subAntarctic and Antarctic waters, and may represent an important food source for whales and large fish (VAN DER SPOEL; DADON, 1999). The gymnosomes are also frequent but usually in low abundances, showing a very patchy distribution since most species are specialized predators (LALLI; GILMER, 1989). The presence and density of thecosomes and gymnosomes are affected by ecosystem changes (HUNT et al., 2008). Salps can be important during spring and summer through the formation of blooms, when they can be significant grazers of primary production. They consume a wide range of food particles with $100 \%$ efficiency (FORTIER et al., 1994; MADIN; CETTA, 1984) competing effectively with other primary consumers. Chaetognaths are active predators and constitute a link in the transfer of energy from copepods (their primary prey) to higher trophic levels (TERAZAKI, 1998). Planktonic polychaetes include both grazers and voracious predators (PETTIBONE, 1963), but are less abundant than chaetognaths. Some species may, at times, be the dominant forms in the plankton community and can be of considerable importance as food for fishes (PETTIBONE, 1963). Available data indicate that pteropods, polychaetes, salps and chaetognaths are regionally significant components of the Southern Ocean pelagic ecosystem. It was on this basis that the present work studied the frequency and density of species, their relationship with some environmental variables, and the horizontal and vertical distribution patterns of these mesozooplankton groups around the islands of South Georgia and South Orkney and the WeddellScotia Confluence to expand the information available on their ecological aspects.

\section{Material ANd Methods}

The South Georgia Island (SG, 53 ${ }^{\circ} 10^{\prime}$ $55^{\circ} 48^{\prime} \mathrm{S}$ and $34^{\circ} 4^{\prime}-39^{\circ} 8^{\prime} \mathrm{W}$ ) and the South Orkney Islands (SO, $57^{\circ} 37^{\prime}-61^{\circ} 1$ 'S and $45^{\circ} 14^{\prime}-50^{\circ} 31^{\prime} \mathrm{W}$ ) are located in the Atlantic sector of the Southern Ocean (Fig. 1). The Antarctic Circumpolar Current (ACC) flows eastward around the Antarctic continent as a series of parallel strips delimited by fronts, including the Polar Front (PF) to the north, the Southern Front of the Antarctic Circumpolar Current (SACCF) and the Southern Boundary of the Antarctic Circumpolar Current (SBACC) to the south (ORSI et al., 1995). SG is a mountainous island with a broad continental shelf, located in the Antarctic Zone between the PF to the north and the SACCF to the south. The SACCF, as hown in Figure 1 turns around the entire continental shelf of the island from the south to the west and north because of the particular bathymetry of the region, giving rise to eddies and meanders (THORPE et al., 2002; WARD et al., 2002). The surface water around the islands consists of Antarctic Superficial Water (ASW), whose salinity and temperature vary, respectively, between 33 and 34.5 in summer and $1.9^{\circ} \mathrm{C}$ and $1{ }^{\circ} \mathrm{C}$ in winter and $-1^{\circ} \mathrm{C}$ and $4^{\circ} \mathrm{C}$ in summer (ORSI et al., 1995).

The SO islands are located outside the ACC, south of the SBACC, in the Subpolar Zone (Fig. 1) north of the Weddell Gyre, an area that remains frozen from mid-March to early December. The ASW around SO presents average values of salinity and temperature of 33.9 and $0.8^{\circ} \mathrm{C}$ respectively (ORSI et al., 1995). The area between SG and SO (Fig. 1) includes the interface between the Weddell and Scotia seas, the WeddellScotia Confluence (WSC), often located to the north of SO (DEACON, 1982; PATTERSON; SIEVERS, 1980) and to the south of the SBACC.

A total of 383 samples were collected in 1995 from 104 oceanographic stations located around SO (March 11-23) and SG (February 10-24 and March 25April 2). Sampling was carried out on board the R.V. Dr. Eduardo L. Holmberg. Figure 1 shows the study area, the locations of the oceanographic stations sampled and the mean position of the PF, SACCF and SBACC, according to Orsi et al. (1995). Oceanographic data were obtained at each sampling station with a Neil Brown Instrument Systems (NBIS) MKIIIB CTD profiler (data in TOSONOTTO, 2000).

Zooplankton samples were taken in oblique tows using a Nansen net $(0.70 \mathrm{~m}$ mouth opening, $200 \mu \mathrm{m}$ mesh size) equipped with a flowmeter, at four depth strata $(0-25,25-50,50-100$, and 100-200 m). The samples were preserved in $5 \%$ buffered formaldehyde. All the polychaetes, chaetognaths and salps were sorted out, stained with methylene blue, identified under a dissecting microscope and counted. Aliquots containing at least 100 individuals of Thecosomata were obtained with a Russell subsampler (due to the large number of organisms in this group), identified and counted.

To analyze the vertical distribution pattern of the most frequent species, the density $(\log x+1)$, where $x=i n d / 1000 \mathrm{~m}$, was compared as between day and night for each stratum using analysis of variance (ANOVA) with two fixed factors: stratum (levels: 0$25,25-50,50-100$, and $100-200 \mathrm{~m}$ ) and time of the day (levels day and night). When appropriate, post-hoc comparisons were made with the Tukey test. Assumptions of normality and homoscedasticity were previously tested with Kolmogorov-Smirnov and Bartlett's tests, respectively (SOKAL; ROHLF, 1997). Differences were considered statistically significant at $\mathrm{p}<0.05$. 


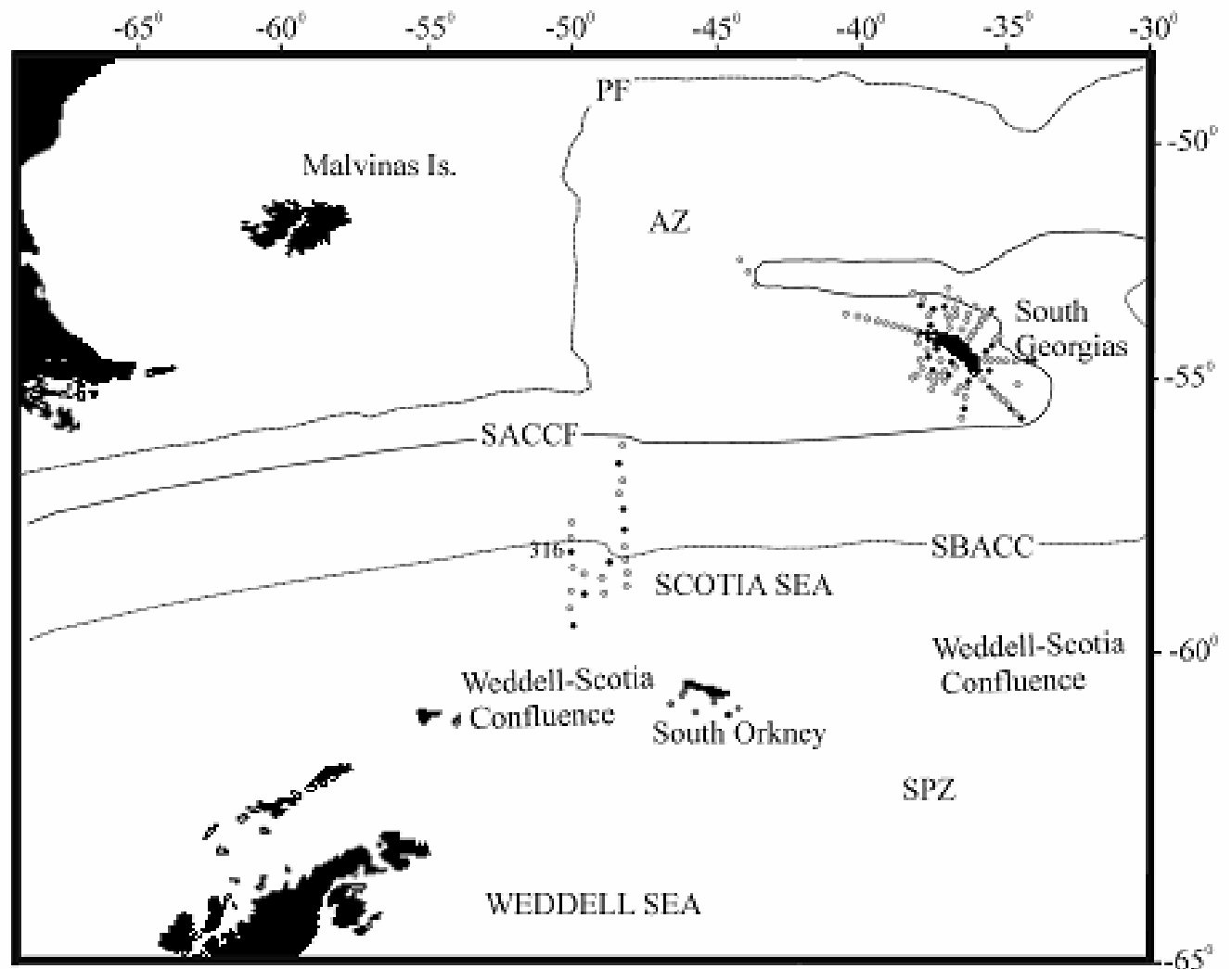

Fig. 1. Sampling area and position of the oceanographic stations taken by day (grey dots) and night (black dots) in summer 1995, around South Georgias Islands, South Orkney Islands and Weddell-Scotia Confluence. PF: mean position of the Polar Front (according to Orsi et al.1995), SACCF: South Antarctic Circumpolar Current Front, SBACC: Southern Boundary of the Antarctic Circumpolar Current, AZ: Antarctic Zone, SPZ: Sub Polar Zone, 316: northernmost station of the Weddell-Scotia Confluence.

The relationships between the density (ind./1000 m) of each species and the following environmental and spatial-temporal variables: temperature, salinity, mean depth, distance to the bottom, day length and time of the day, were analyzed with the canonical correspondence analysis method (CCA, TER BRAAK, 1987, 1990) using the CANOCO program. Latitude and longitude were used as co-variables.

\section{RESUltS}

The variations in salinity and temperature found at SG, SO and the WSC are shown in Figures 2 $(\mathrm{a}, \mathrm{b})$. Around SG, salinity varied between 33 and 34.3 and temperature between 5.4 and $3.0^{\circ} \mathrm{C}$. Around San Pedro Island (the main SG island), a temperature drop from $3.0^{\circ} \mathrm{C}$ to $1.5^{\circ} \mathrm{C}$, and an increase in salinity from 33.7 to 34.3 , can be observed when transposing the SACCF (Figs 2 a, b). Around SO the ASW presented salinities between 34.3 and 33.7 and temperatures between $1.5^{\circ} \mathrm{C}$ and $0.8^{\circ} \mathrm{C}$.

Although the PF was undetected during the sampling, it is known to occur in the vicinity of SG (GORDON, 1971; ORSI et al., 1995) and its average location is shown in Figure 1. The greatest variations in temperature and salinity were observed at the WSC.

The species found in the present study included the chaetognaths: Eukrohnia hamata (Möbius), 1875, Sagitta gazellae Ritter-Zahony, 1909; the pteropods Clione limacina antarctica, (Smith, 1902), Spongiobranchaea australis d'Orbigny, 1836, Clio sulcata (Pfeffer, 1879), Limacina helicina (Phipps, 1774), Limacina retroversa (Fleming, 1823); the polychaetes, Pelagobia longicirrata Greeff, 1879, Rhynchonereella bongraini (Gravier, 1911), Tomopteris carpenterii Quatrefages 1866, Tomopteris planktonis Apstein, 1900, Tomopteris septentrionalis Quatrefages, 1866 (Polychaeta), and the salp Salpa thompsoni (Salpidae) Foxton, 1961. 
The species frequency of occurrence differed between oceanic areas. Around the SG, $L$. retroversa appeared in $76 \%$ of the samples, $P$. longicirrata in $44 \%, E$. hamata in $34 \%$, and $S$. gazellae in $16 \%$. In the Weddell-Scotia Confluence, the most frequent species were $P$. longicirrata and $S$. thompsoni (55\% of the samples) followed by $L$. retroversa (29\%) and E. hamata (22\%). The frequency of $L$. helicina was similar in both areas (74-76\%) and only juveniles of E. hamata and $S$. gazellae were found. The remaining species showed a frequency lower than $16 \%$. Around SO the highest frequency was that of L. helicina (75\%), followed by P. longicirrata (12.5\%), the only two species found.
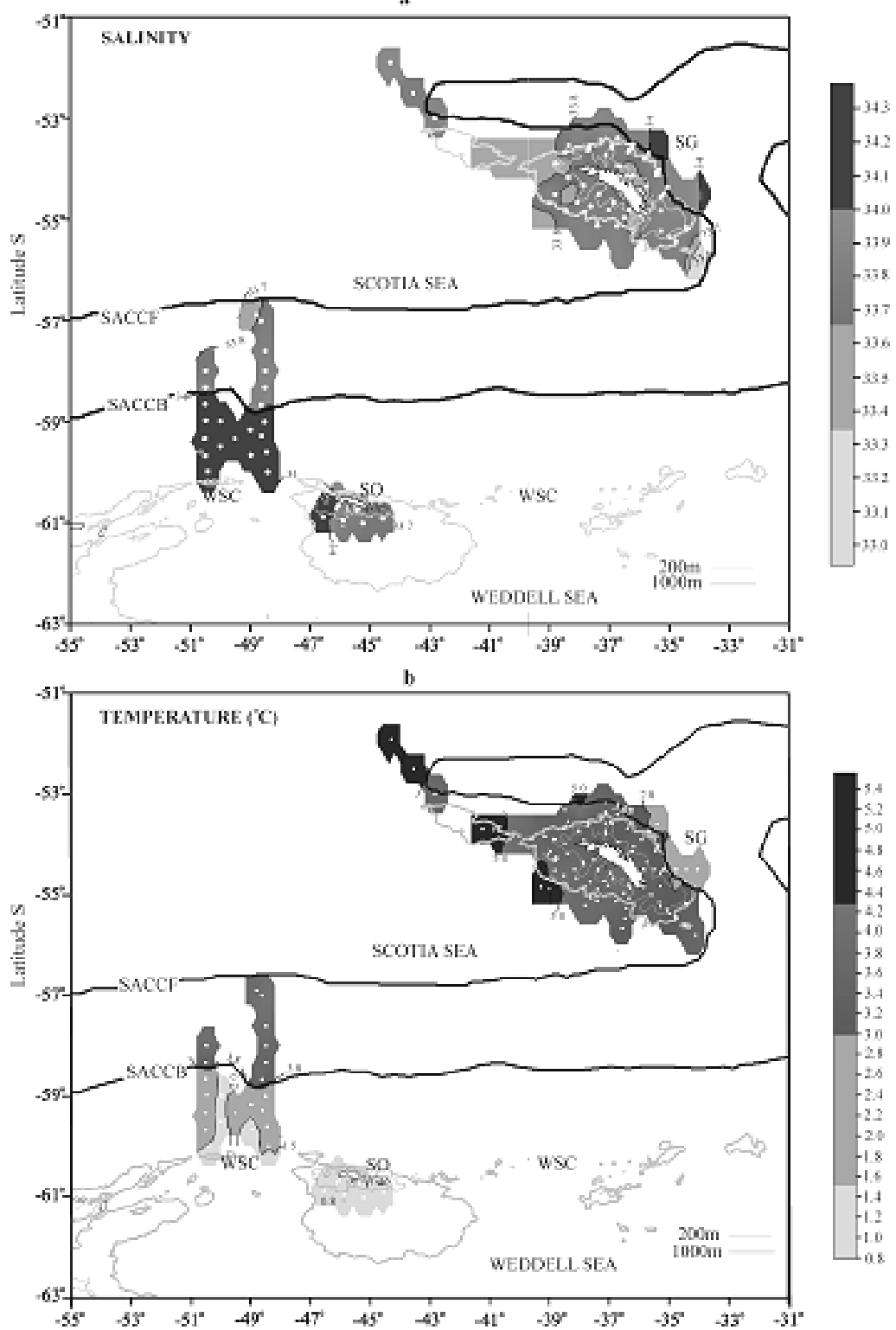

Fig. 2. Horizontal distribution of Temperature $\left({ }^{\circ} \mathrm{C}\right)$ and Salinity at South Georgias Islands (SG), South Orkney Islands (SO) and Weddell-Scotia Confluence (WSC). White dots: Sampled stations, PF: Polar Front, SACCF: South Antarctic Circumpolar Current Front, SBACC: Southern Boundary of the Antarctic Circumpolar Current. 316: northernmost station of the Weddell-Scotia Confluence. 
Horizontal and Vertical Distribution of the Species

\section{Thecosomata}

Limacina helicina was found at most stations. Its density varied between 25 and 4076 x 10 ind./1000 $\mathrm{m}$, being highest to the south and east of $\mathrm{SG}$, intermediate in the WSC and lowest around the SO (Figs 3 a, b). It was found in all the strata studied (Figs $4 \mathrm{a}, \mathrm{b}$ ), its density being significantly higher at nighttime (Table 1).
Limacina retroversa had a similar distribution to that of L. helicina but occurred at higher densities (19 and $71 \times 10$ ind./1000 m). Its abundance was higher at SG, decreased in the WSC and only a few individuals were found at SO (Figs $3 \mathrm{c}$, d). Around SG, densities increased significantly at night, with maximum values for the uppermost stratum (Table 1). In the WSC, it was found exclusively at night, with a higher density at between 50-100 m depth (Figs $4 \mathrm{c}, \mathrm{d}$ ).
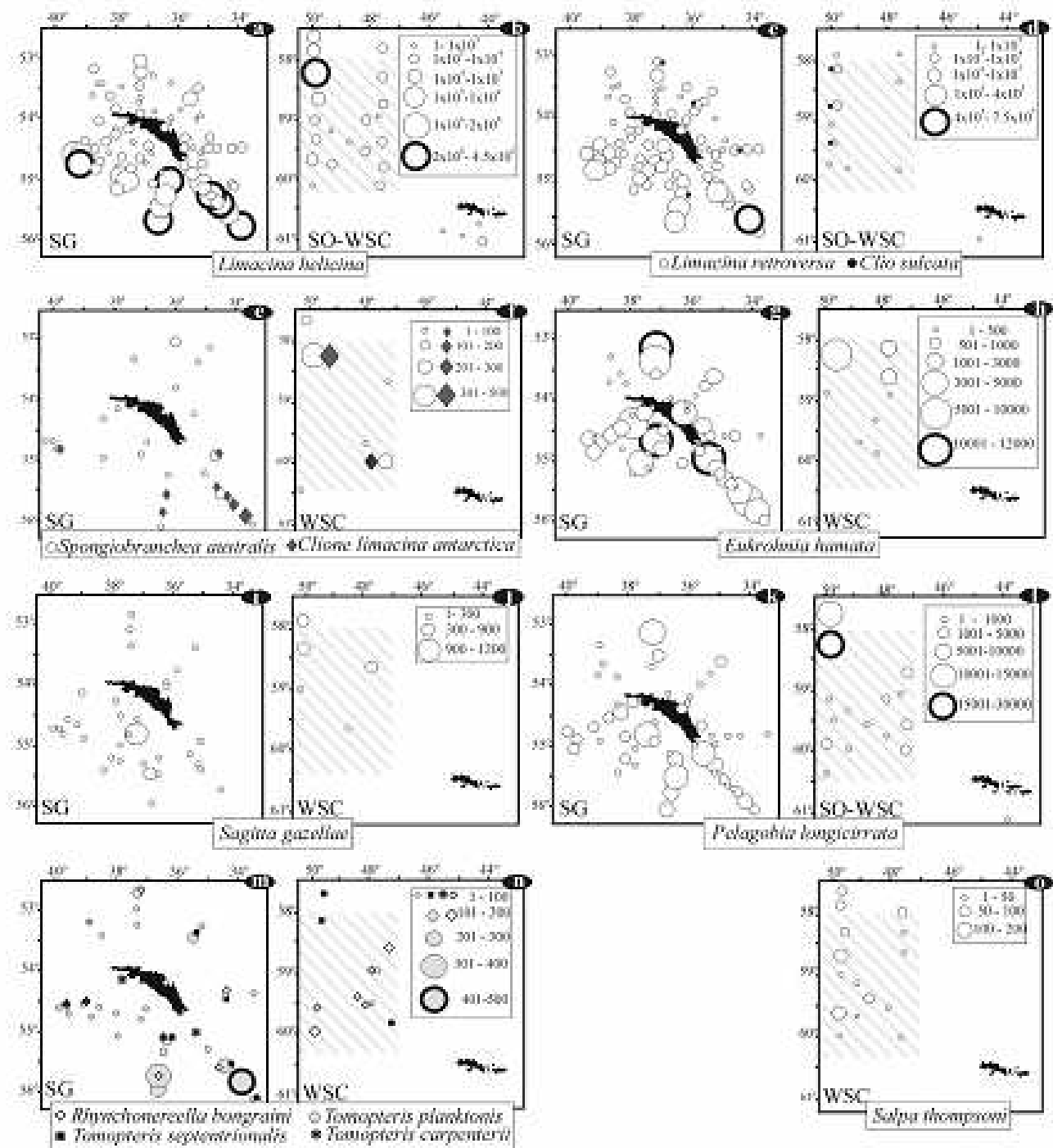

Fig. 3. Density (individuals per $1000 \mathrm{~m}$ ) and horizontal distribution of the species recorded around South Georgia Islands (SG), South Orkney Islands (SO) and at the Weddell Scotia Confluence (striped area). Limacina helicina (a, b), Limacina retroversa (c, d), Clio sulcata (c, d), Spongiobranchea australis (e, f), Clione limacina antarctica (e, f), Eukrohia hamata (g, h), Sagitta gazellae (i, j), Pelagobia longicirrata (k, 1), Rhyncohereella bongraini (m, n) Tomopteris planktonis $(\mathrm{m}, \mathrm{n})$, Tomopteris septentrionalis $(\mathrm{m}, \mathrm{n})$, Tomopteris carpenterii $(\mathrm{m}, \mathrm{n})$, Salpa thompsoni (o). 

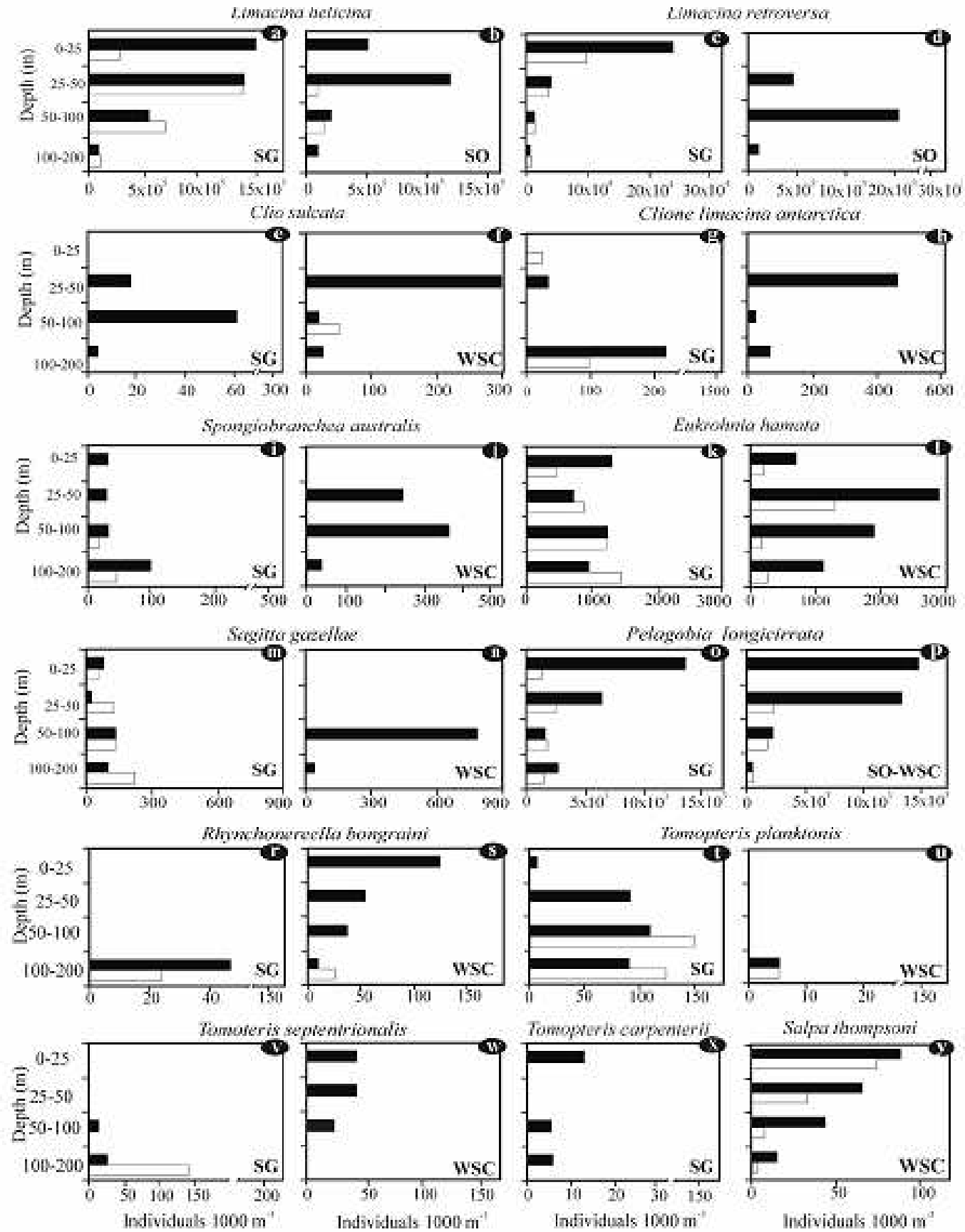

Fig. 4. Density (individuals per $1000 \mathrm{~m}$ ) and vertical distribution of the species recorded around the South Georgia Islands (SG), South Orkney Islands (SO), the Weddell-Scotia Confluence (WSC). Limacina helicina (a, b), Limacina retroversa (c, d), Clio Sulcata (e, f), Clione limacina antarctica $(\mathrm{g}, \mathrm{h})$, Spongiobranchea australis $(\mathrm{i}, \mathrm{j})$, Eukrohia hamata $(\mathrm{k}, 1)$, Sagitta gazellae $(\mathrm{m}, \mathrm{n})$, Pelagobia longicirrata $(\mathrm{o}, \mathrm{p})$, Rhyncohereella bongraini $(\mathrm{r}, \mathrm{s})$ Tomopteris planktonis $(\mathrm{t}, \mathrm{u})$, Tomopteris septentrionalis $(\mathrm{v}, \mathrm{w})$, Tomopteris carpenterii (x), Salpa thompsoni (y). 
Table 1. Results of the analyses of variance (ANOVA) of two fixed factors: stratum (four levels: $1=0-25,2=25-50,3=50-100$, 4=100-200 m) and time of the day (day/night); and Tukey's "a posteriori" comparisons. In bold: $\mathrm{P}<0.05$.

\begin{tabular}{|c|c|c|c|c|c|c|c|}
\hline & \multicolumn{2}{|c|}{ Stratum } & \multicolumn{2}{|c|}{ Day/Night } & \multicolumn{2}{|c|}{$\begin{array}{l}\text { Stratum x } \\
\text { Day/Night }\end{array}$} & \multirow{2}{*}{$\begin{array}{l}\text { Tukey's comparisons } \\
\text { Stratum }\end{array}$} \\
\hline & $\mathrm{F}$ & $\mathrm{P}$ & $\mathrm{F}$ & $\mathrm{P}$ & $\mathrm{F}$ & $\mathrm{P}$ & \\
\hline E. hamata & 2.203 & 0.092 & .044 & 0.835 & 0.041 & 0.989 & 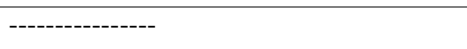 \\
\hline L. helicina & 0.692 & 0.558 & 7.696 & 0.006 & 0.078 & 0.972 & ------------------ \\
\hline L. retroversa & 2.888 & 0.037 & 8.552 & 0.004 & 2.185 & 0.091 & $\overline{\mathrm{X}}_{1}>\overline{\mathrm{X}}_{4}(\mathrm{P}=0.034)$ \\
\hline P. longicirrata & 2.084 & 0.105 & 9.258 & 0.003 & 0.272 & 0.846 & 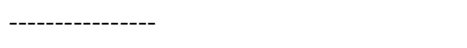 \\
\hline S. gazellae & 4.024 & 0.010 & 0.383 & 0.537 & 0.439 & 0.726 & $\overline{\mathrm{X}}_{1}<\overline{\mathrm{X}}_{4}(\mathrm{P}=0.022) \overline{\mathrm{X}}_{2}<\overline{\mathrm{X}}_{4}(\mathrm{P}=0.040)$ \\
\hline T. planktonis & 12.472 & 0.001 & 1.289 & 0.259 & 1.219 & 0.308 & $\begin{array}{ll}\overline{\mathrm{X}}_{1}<\overline{\mathrm{X}}_{3}(\mathrm{P}=0.001) & \overline{\mathrm{X}}_{1}<\overline{\mathrm{X}}_{4}(\mathrm{P}=0.001) \\
\overline{\mathrm{X}}_{2}<\overline{\mathrm{X}}_{3}(\mathrm{P}=0.018) & \overline{\mathrm{X}}_{2}<\overline{\mathrm{X}}_{4}(\mathrm{P}=0.001)\end{array}$ \\
\hline
\end{tabular}

Clio sulcata was a rare species with a patchy distribution, showing the lowest density around SG (ca . 28 ind./1000 $\mathrm{m}$ ) and the highest density in the WSC (100 ind./1000 m). It was not found around SO (Figs $3 \mathrm{c}$, d) and was almost completely absent during the day and, although abundant at night, it did not migrate into the $0-25$ m layer (Figs 4 e, f).

\section{Gymnosomata}

Clione limacina antarctica was recorded at a few stations located to the south and east of SG and in the WSC, while it was absent around SO (Figs 3 e, f). The highest abundance (450 ind./1000 m) was observed at the northernmost station of the WSC, densities tending to increase at night and below $25 \mathrm{~m}$ depth (Figs 4 g, h). Spongiobranchaea australis was more frequent around SG, less frequent in the WSC and absent at SO. Density ranged between 13 ind./1000 $\mathrm{m}$ around $\mathrm{SG}$ to 375 ind./1000 $\mathrm{m}$ at the northernmost station of the WSC (Fig 3 e, f). Densities tended to increase at night and between $50-100 \mathrm{~m}$ depth (Figs 4 i, j).

\section{Chaetognatha}

Eukrohnia hamata was the most frequent and abundant chaetognath species. It was more frequent around SG, decreased in the WSC and was absent around SO (Figs $3 \mathrm{~g}$, h). Density ranged between 15 and 5330 ind./1000 m, higher values being found north of 59 $40^{\prime}$. It was present at all depths (Fig. $4 \mathrm{k}, 1)$ and no significant differences were found among strata (Table 1). Abundance tended to increase at night around SO. Most of the individuals found between 0-200 $\mathrm{m}$ depth were at stage I (ovaries as small round bodies, testes as thin tubes) and theremainder, which were at stage II (ovaries and testes undergoing development, seminal vesicles absent), were found below $150 \mathrm{~m}$ depth.

Sagitta gazellae was only found around SG and in the WSC. It was more frequent to the south of SG and density was higher at offshore stations (1052 ind./1000 m), with values decreasing southward (Fig. $3 \mathrm{I}, \mathrm{J})$. There were significant differences in density among strata (Table 1). Density was higher between 100-200 m depth at SG and 50-100 m at WSC (Figs 4 $\mathrm{m}, \mathrm{n})$. All individuals were at stage I.

\section{Polychaeta}

Pelagobia longicirrata was the most frequent and abundant polychaete species. Its density ranged between 11 and 10810 ind./1000 m around SG, was higher $(29170$ ind./ $1000 \mathrm{~m})$ at stations north of the WSC and decreased toward SO, where it was only found at one station (Fig. $3 \mathrm{k}, 1$ ). In general, density was higher to the south and east of SG (off the shelf) and at night. This latter fact was evidenced by large nighttime densities in the 25-50 and 0-25 strata (Figs 4 $o, p)$. Although there were no significant differences among strata (Table 1), this species was more abundant between 50-0 m depth.

Rhynchonereella bongraini was a rare species with a patchy distribution, occurring at a few stations around SG. The highest density (117 ind. $/ 1000 \mathrm{~m}$ ) was reached in the south of the WSC but the species was absent at $\mathrm{SO}$ (Figs $3 \mathrm{~m}$, n). It was found in all strata of the WSC, but only between $100200 \mathrm{~m}$ at SG; its density tended to increase at night (Figs $4 \mathrm{r}, \mathrm{s}$ ).

Tomopteris planktonis was found scattered throughout the study area, with densities between 9 and 498 ind./1000 $\mathrm{m}$. The higher densities were recorded offshore, to the southeast of SG and the lowest to the north of SO (Figs 3 m, n). Density varied 
significantly between strata (Table 1), with higher values between 100 and $200 \mathrm{~m}$ depth (Figs $4 \mathrm{t}$, u). At SG a distinct diel migration was evident.

Tomopteris septentrionalis was found at a few stations around SG, mainly to the southeast of the islands, and was absent at latitudes below $59^{\circ} 40^{\prime} \mathrm{S}$. Density ranged between 13 and 498 ind./1000 $\mathrm{m}$ (Figs $3 \mathrm{~m}, \mathrm{n}$ ), and was higher at night (Figs $4 \mathrm{v}, \mathrm{w}$ ).

Tomopteris carpenterii was only found at a few stations to the south of SG, from 0 to $200 \mathrm{~m}$, with densities between 11 and 26 ind. $/ 1000 \mathrm{~m}$ (Figs $3 \mathrm{~m}$, n), and exclusively at night (Fig. $4 \mathrm{x}$ ).

\section{Salpidae}

Salpa thompsoni was found between 57 and $59^{\circ} \mathrm{S}$ and was absent around SG. The oozooid/blastozooid ratio was 1:36. Density ranged between 19 and 189 ind./1000 $\mathrm{m}^{3}$ (Fig. 3o) with higher values at night (Fig. 4 y).

\section{Statistical Analysis}

The following variables were significant in the CCA: mean depth $(p=0.001)$, distance to the bottom $(\mathrm{p}=0.001)$, day length $(\mathrm{p}=0.001)$, and mean temperature $(\mathrm{p}=0.013)$. Figure 5 shows the resulting ordination diagram. The results did not show separate groups of species clearly, they seemed rather to be arranged along the mean depth and temperature axes. Limacina helicina, $L$. retroversa and Pelagobia longicirrata are more likely to be related to lower mean depths and higher temperatures, whereas $R$. bongraini, $T$. septentrionalis and $C$. limacina antarctica showed the opposite pattern. In the area around SO, the species were not clustered according to the environmental or spatial variables considered $(\mathrm{p}>0.05)$.

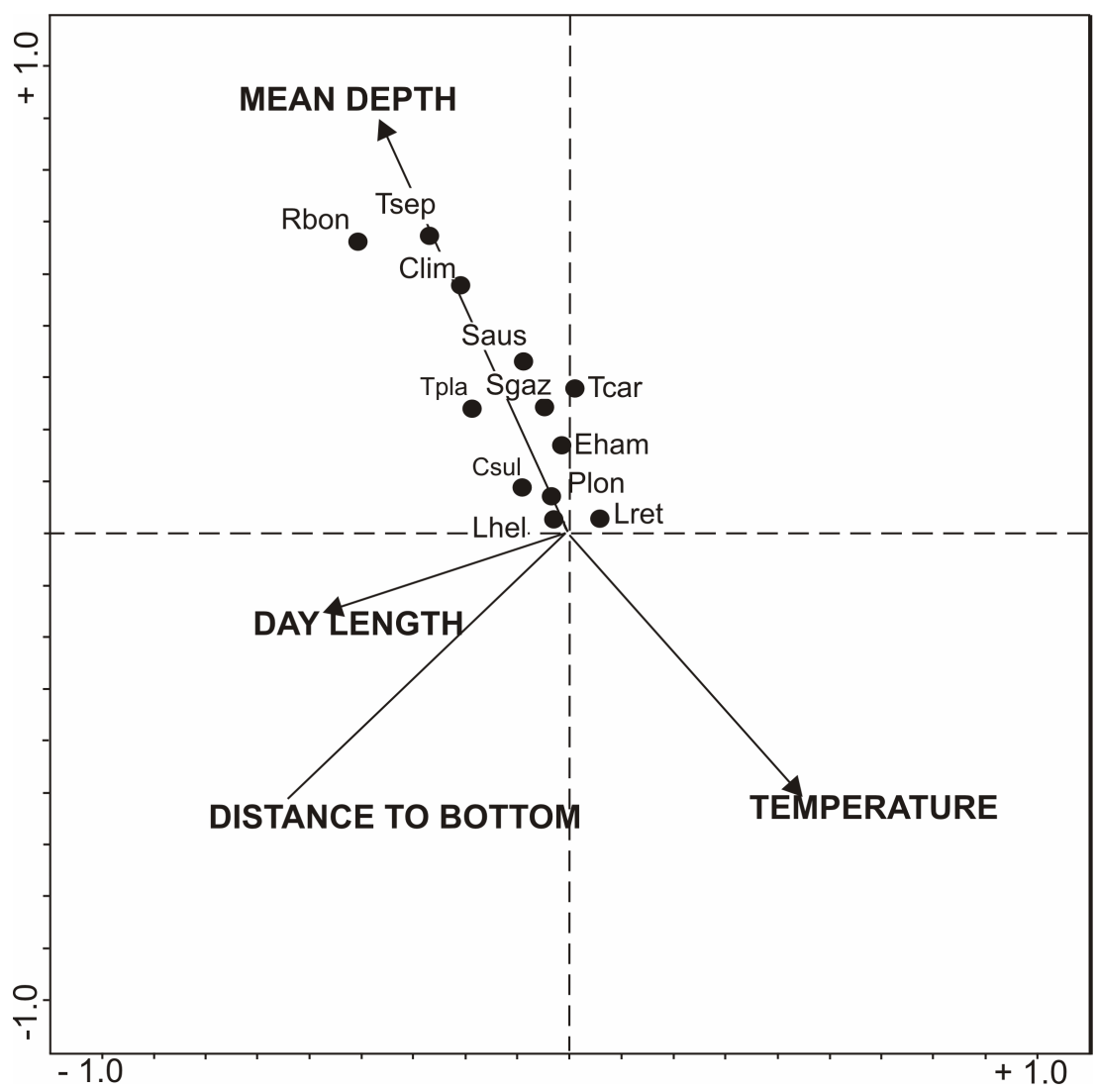

Fig. 5. Canonical Correspondence Analyses, biplot for species and significant environmental variables. Clim: Clione limacina antarctica, Csul: Clio sulcata, Eham: Eukrohnia hamata, Lhel: Limacina helicina, Lret: Limacina retroversa, Plon: Pelagobia longicirrata, Rbon: Rhynchonereella bongraini, Sgaz: Sagitta gazellae, Saus: Spongiobranchaea australis, Tcar: Tomopteris carpenterii, Tpla: Tomopteris planktonis, Tsep: Tomopteris septentrionalis. 


\section{Discussion AND CONCLUSIONS}

The salinity and temperature values recorded agree with the average surface values obtained by Orsi et al. (1995) for the month of February (33.9 and $\left.0.8^{\circ} \mathrm{C}\right)$. However, the temperature found south of SO $\left(0.8^{\circ} \mathrm{C}\right)$ is higher than the expected value for the ASW of the Weddell Sea in late March. Probably this increase indicates the intrusion of water from the CWS in the north of the Weddell Gyre (Isbert Perlender, unpublished data).

Differences were found in the abundance and distribution patterns of the different taxa. The South Georgia islands showed the highest number of species (13) and abundance, followed by the WSC, with the same number of species but registering lower abundances, and by SO with only 2 species and the lowest densities.

Pteropoda outnumbered all the other taxa analyzed by a factor of $100, L$. helicina and $L$. retroversa being the most abundant. The density of $\mathrm{L}$. helicina was almost twice the value reported by Pvakhomo and Perissinotto (1997), 4076 ind ./mvs 2681 ind. /m respectively, while that of $L$. retroversa was relatively close to the one reported by Hunt et al. (2008), 710 ind./mvs 807 ind./m. Limacina spp contributed significantly to the total zooplankton number, with higher values than those found for Euphausia spp, an important heterotrophic group. Gallotti and Marschoff (2004) showed, during the same survey, that larval stages of Euphausia superba were only found at a few stations around SG with densities $<500$ ind./m, whereas in the WSC they were highly frequent and reached a density of about 1000 ind./m. Polychaeta was the second group in abundance, among the species encountered Tomopteris planktonis, T. septentrionalis and Pelagobia longicirrata were considered to be cosmopolitan, $P$. longicirrata was, however, the only one also present in SO. Its presence at temperatures between 3.2 and $0.8^{\circ} \mathrm{C}$ coincides with that recorded by Day (1967) who proposed that despite its cosmopolitan character, it has an affinity for cold waters. Although Rinchonereela bongraini is abundant in Antarctic and sub-Antarctic waters (TEBBLE, 1960; ORENSANZ; RAMIREZ, 1975) and $T$. carpenterii is endemic to Antarctic waters (TEBBLE, 1960), both species were found in low frequency and density. Among chaetognats, Eukrohnia hamata was the dominant species, with much higher densities around SG than those reported for the same area by Atkinson and Peck (1988) for the summer 19811982. The highest abundance of juveniles was found in the upper strata whereas adults were found at a greater depth. This fact suggests ontogenic migration along the water column. The vertical distribution of the adults of $E$. hamata and Sagitta gazzellae coincides with those given in other studies undertaken in the area investigated (HAGEN 1985; DURÓ et al., 1999). However, Duró and Gili (2000) reported higher densities of juveniles of both species in deeper layers of the Weddell Sea $(1000-500 \mathrm{~m})$ during late austral spring, suggesting that this result was related to an adaptation of the life cycle of these species to the hard seasonal conditions of the Antarctic.

Although Salpa thompsoni is the most abundant and common salp species in the Southern Ocean, it was not found off SG or SO in this study. Its absence around SG may be related to elevated chlorophyll-a concentrations usually present in the area (GILPIN et al., 2002; ATKINSON et al., 2001). High phytoplankton concentrations can cause the clogging of the salps' filter feeding system (HARBISON; MCALISTER, 1979) which may lead to the inability to feed. Perissinotto and Pakhomov (1998) found that $S$. thompsoni virtually disappeared when chlorophyll-a concentrations reached levels between 1.5 and $3 \mathrm{mg} . / \mathrm{m}$, suggesting that this species prefers waters with intermediate values of phytoplankton. Deibel (1985) found that at high food concentration, the muscular contraction of salps became shallow and irregular, causing a decline of the clearance rate and the clogging of the filtering apparatus. Temperature also affects muscular contraction, and in some species, the temperature decrease produces a slowing or a cessation of muscular contraction, thereby affecting the feeding rate. Further, some observations suggest that the population growth of Salpa thompsoni is slower in the ice-edge area (CASARETO; NEMOTO, 1986). The influence of the cold waters from the Weddell Sea is probably the cause of the absence of this species to the south of SO, while the intermediate values of temperature and chlorophyll-a found in the WSC would favor the occurrence of $S$. thompsoni in this area. On the other hand, our results indicated that this species reached its highest density in the euphotic zone of the open ocean in both day and nighttime. The 1:36 oozooid: blastozooid ratio found in this study and the presence of young blastozooids suggests that the oozooids were reproducing actively. However, the population did not reach the densities commonly observed in summer (1000 ind./1000 m) during blooms as was found by Chiba et al. (1999). Although the most frequent species around SG, L. helicina, $L$. retroversa and $P$. longicirrata, were found at all the depths studied, they were more abundant between 0 and $100 \mathrm{~m}$ depth. The vertical variations in their density may be due to diel migrations and to a lesser extent to net avoidance. Many pteropod species show low densities in shallow waters, when they migrate to deeper strata, and higher densities at night, when they migrate upwards. In addition, Støp-Bowitz (1981) suggested net avoidance for the polychaete $P$. 
longicirrata, but this behavior was not observed in $L$. helicina or L. retroversa (VAN DER SPOEL; BOLTOVSKOY, 1981). The dominance of L. helicina juveniles observed in this study may be due to ontogenetic vertical migration with the adults occurring deeper in the water column, as reported by KOBAYASHI (1974).

The high chlorophyll-a concentrations frequently recorded in the area around SG (GILPIN et al., 2002; ATKINSON et al., 2001) may be related to the high concentrations of nutrients introduced from the east, via the SACCF (KORB et al. 2004) and may be associated with the remarkably high density and frequency of pteropod species, especially L. helicina and $L$. Retrovers, to the south of SG. These phytoplankton blooms support a high biomass of filter-feeding zooplankton such as krill, copepods and pteropods, which may, in their turn, support high densities of predators like E. hamata and S. gazellae. Sub-Antarctic water intrusions detected to the south of San Pedro Island (the main island of SG) could explain the high densities of $L$. retroversa, a species characteristic of sub-Antarctic waters (DADON; MASELLO, 1999; DADON; ESNAL, 1995). The high abundance of species found at station 316 (Fig. 1), located between SACCF and SB, could be related to the presence of eddies carrying organisms from the north, including species inhabiting sub-Antarctic waters.

Contrary to Van Der Spoel's (1967) conclusions, our results suggest that the Polar Front (Fig. 1), which has been historically located some distance to the north of the sampling area (ORSI et al., 1995), is not the southern limit of the distribution of stenoecious zooplankters, particularly thecosome pteropods. On the mesoscale, the sporadic presence of $L$. retroversa around $\mathrm{SO}$ would indicate that the WSC is the southern distribution limit of this strictly subantarctic mesozooplankton species. This study extends the known distribution of $L$. retroversa further south, near the WSC. Although most of the species were distributed around SG and in the WSC, the densities of $C$. limacina antarctica and $S$. australis were, respectively, two to four times higher in the WSC than off SG. The opposite pattern was found for $L$. retroversa, $T$. planktonis, $T$. carpenterii and $S$. thompsoni, whose densities decreased markedly toward the WSC and were absent at stations near SO. Thus the WSC seems to be the southern distribution limit of these species, probably due to the abrupt decrease in temperature (from 4.2 to $0.9^{\circ} \mathrm{C}$ ) and salinity (from 33.9 to 34.3 ) in surface waters. None of the distribution of the species found in this analysis seems to be affected by the SBACC.

\section{ACKNOWLEDGMENTS}

We would like to thank the Instituto Antártico Argentino (IAA) and Dr. Enrique Marschoff for providing the samples. We are also grateful for the important suggestions made by the two anonymous referees. This study was funded by the project UBACYT X074 (Universidad de Buenos Aires).

\section{REFERENCES}

ATKINSON, A. Life cycle strategies of epipelagic copepods in the Southern Ocean. J. mar. Syst., v. 15, p. 289-311, 1998.

ATKINSON, A.; PECK, J.M. A Summer-Winter comparison of zooplancton in the Oceanic Area around South Georgia. Polar Biol., v. 8, p. 463-473, 1988.

ATKINSON, A.; WHITEHOUSE, M. J.; PRIDDLE. South Georgia, Antarctica: a productive, cold water, pelagic ecosystem. Mar. Ecol. Prog. Ser., v. 216, p. 279-308, 2001.

CASARETO, B. E.; NEMOTO, T. Salps of the southern ocean (Australian sector) during the 1983-84 summer, with special reference to the species Salpa thompsoni, Foxton 1961. Mem.Natl Inst.Polar Res., v. 40, p. 221239, 1986

CHIBA, S.; ISHIMARU,T.; HOSIE,G. W.; WRIGHT,S.W. Population structure change of Salpa thompsoni from austral mid-summer to autumn. Polar Biol., v. 22, p.341349, 1999

DADON, J. R.; ESNAL, G. B. Abundance and assemblages of planktonic Tunicata (Chordata) and Thecosomata (Mollusca) off south Brazil, Physis, (B. Aires) A., v. 50, p. 25-30, 1995.

DADON, J. R.; MASELLO, S. F. Mechanisms generating and maintaining the admixture of zooplanktonic molluscs (Euthecosomata, Opistobranchiata: Gastropoda) in the Subtropical Front of the south Atlantic. Mar. Biol., v. 135, p. 171-179, 1999.

DAY, J. A monograph on the Polychaeta of southern Africa. Part. 1: Errantia. London: British Museum, Natural History, 1967. p. 1-458. . (Publ., v. 656). p.

DEACON, G. E. R. Physical and biological zonation of the Southern Ocean. Deep-Sea Res., v. 29, p. 1-15, 1982.

DEIBEL, D. Clearance rates of the salp Thalia democratica fed naturally occurring particles. Mar. Biol., Berlin, v. 1, p.47-54, 1985.

DURÓ, A.; SABATÉS A.; GILI, J. M. Mesoscale spatial distribution of chaetognath along hydrographic gradients in the South Scotia Sea (Antarctica). Polar Biol., v. 22, p. 195-206, 1999.

DURÓ, A.; GILI, J. M. Vertical distribution and abundance of juvenile chaetognaths in the Weddell Sea (Antarctica). Polar Biol., v. 24, p. 66-69, 2000.

FORTIER, L.; LE FÈVRE, J.; LEGENDRE, L. Export of biogenic carbon to fish and to the deep ocean: the role of large plankton microphages. J. Plankt. Res., v. 16, p. 809839,1994 
FRANSZ, H. G.; GONZALEZ, S. R. Latitudinal metazoan plankton zones in the Antarctic Circumpolar current along $6^{\circ} \mathrm{W}$ during austral spring 1992. Deep-Sea Res. II, v. 44, p. 395-414, 1997.

GALLOTTI, D. S.; MARSCHOFF, E. R. Distribución de larvas de eufausiáceos en las islas Georgias y Mar de Scotia. 2004. 47 p. Tesis (Licenciatura). Facultad de Ciencias Exactas y Naturales, Universidad de Buenos Aires, 2004.

GILPIN, L. C.; PRIDDLE, J.; WHITEHOUSE, M. J.; SAVIDGE, G.; ATKINSON, A. Primary production and carbon uptake dynamics in the vicinity of South Georgia - balancing carbon fixation and removal. Mar. Ecol. Prog. Ser., v. 242, p. 51-62, 2002.

GORDON, A. L. Antarctic Polar Frontal Zone. In: REIDEL, J. L. (Ed.). Antarctic Oceanology I. Antarctic Research Series 15. Washington, DC: American Geophysical Union, 1971. p. 205-221.

HAGEN, W. On the distribution and population structure of Antarctic Chaetognatha. Meeresforschung ( Repts Mar. Res.), v. 30, p. 280-291, 1985.

HARBISON, G. R; MCALISTER, V. L. The filter-feeding rates and particle retention efficiencies of three species of Cyclosalpa (Tunicata, Thaliacea). Limnol. Oceanogr., v. 24, p. 875-892,1979.

HUNT, B.P.V.; PAKHOMOV, E. A.; HOSIE, G.W.; SIEGEL, V.; WARD, P.; BERNARD, K. Pteropods in Southern Ocean ecosystems. Prog. Ocenogr., v. 78, p.193-221, 2008.

KOBAYASHI, K. Growth cycle and related vertical distribution of the thecosomatous pteropod Spiratella ("Limacina") helicina in the central Arctic Ocean. Mar. Biol., v. 26, p. 295-302, 1974.

KORB, R. E.; WHITEHOUSE, M. J.; WARD, P. SeaWiFS in the southern ocean: spatial and temporal variability in phytoplankton biomass around South Georgia. DeepSea Res. II., v. 51, p. 99-116, 2004.

LALLI, C. M.; GILMER, R. W. Pelagic snails: The Biology of holoplanktonic gastropod Mollusks. Palo Alto: Stanford University Press, 1989. 259 p.

MADIN, L. P.; CETTA, C. M. The use of gut fluorescence to estimate grazing by oceanic salps. J. Plankt. Res., v. 6, p. 475-492, 1984.

ORENSANZ, J.; F. RAMÍREZ. Taxonomía y distribución de los poliquetos pelágicos del Atlántico Sudoccidental. Bol. Inst. Biol., v. 21, p. 1-86, 1973

ORSI, A.H.; WHITWORTH, T. III.; NOWLIN, W. D. J. On the meridional extent and fronts of the Antarctic Circumpolar Current. Deep-Sea Res., v. 42, p. 641-673, 1995.

PATTERSON, S. L.; SIEVERS, H. A. The Weddell-Scotia Confluence. J. Phys. Oceanogr., v. 10, p. 1584-1610, 1980.

PAKHOMOV, E. A.; PERISSINOTTO, R. Mesozooplankton community structure and grazing impact in the region of the Subtropical Convergence south of Africa. J. Plankt. Res., v. 19, p. 675-691, 1997.

PERISSINOTTO, R.; PAKHOMOV, E. A. Contribution of salps to carbon flux of marginal ice zone of the Lazarev Sea, Southern Ocean. Mar. Biol., v. 131, p. 2532, 1998.

PETTIBONE, M. H. Marine Polychaete worms of the New England region. 1. Families Aphroditidae through
Trochochaetidae. Bull. U. S. natn. Mus., v. 227, p. 1356, 1963.

SIGLEO, A. C.; NEALE, P. J.; SPECTOR, A. M. Phytoplankton pigments at the Weddell Scotia confluence during the 1993 austral spring. J. Plankt. Res., v. 22, p. 1989-2006, 2000.

SOKAL, R. R.; ROHLF, F. J. Biometry: The principles and practice of Statistics in biological research. New York: Freeman, 1997. 859 p.

STØP-BOWITZ, C. Polychaeta. In: BOLTOVSKOY, D. (Ed.) Atlas del zooplancton del Atlántico sudoccidental y métodos de trabajo con el zooplancton marino. Publ. Especial Inst. Inv. Des. Pesq. Argentina, 1981. p 471-492.

TEBBLE, N. Distribution of pelagic polychaetes in the South Atlantic Ocean. Discovery Rep., v. 30, p. 161-300, 1960

TERAZAKI, M. Life history, distribution, seasonal variability and feeding of the pelagic chaetognath Sagitta elegans in the Subarctic Pacific: a review. Plankton Biol. Ecol., v. 45, p. 1-17. 1998.

TER BRAAK, C. J. F. CANOCO. A FORTRAN program for canonical community ordination by [partial] [detrended] [canonical] correspondence analysis, principal components analysis and redundancy analysis (version 2.1). Wageningen, The Netherlands: TNO Institute of Applied Computer Science, Statistics Department, 1987.

TER BRAAK, C. J. F. Updates notes: CANOCO version 3.10. Wageningen, The Netherlands: Agricultural Mathematics Group, 1990.

THORPE, S. E.; HEYWOOD, K. J.; BRANDON, M. A.; STEVENS, D. P. Variability of the southern Antarctic Circumpolar Current front north of South Georgia. J. mar. Syst., v. 37, p. 87-105. 2002.

TOSONOTTO, G. V. Datos de CTD correspondientes a la Campaña a bordo del BIP “Dr. Holmberg”, 1995. Instituto Antártico Argentino, 2000. Contribución no. 490.

VAN DER SPOEL, S. Euthecosomata, a group with remarkable developmental stages (Gastropoda, Pteropoda). J. Nooduijn en Zoom N V Gorinchem, 1967. $386 \mathrm{p}$.

VAN DER SPOEL, S.; BOLTOVSKOY, D. Pteropoda. In: BOLTOVSKOY, D. (Ed.). Atlas del zooplancton del Atlántico sudoccidental y métodos de trabajo con el zooplancton marino. Publ Especial Inst. Inv. Des. Pesq. Argentina. 1981. p. 493-531.

VAN DER SPOEL, S.; DADÓN, J. R. Pteropoda. In: BOLTOVSKOY, D. (Ed.) . South Atlantic Zooplankton. Leiden: Backhuys Pub., 1999. p. 649706.

VORONINA, N. M. Comparative abundance and distribution of major filter-feeders in the Antarctic Pelagic zone. J. mar. Sys., v. 17, p. 375-390, 1998.

WARD, P.; WHITEHOUSE, M.; MEREDITH, M.; MURPHY, E.; SHREEVE, R.; KORB, R.; WATKINS, J.; THORPE, S.; WOODD-

WALKER, R.; BRIERLEY, A.; CUNNINGHAM, N.; GRANT, S.; BONE, D. The Southern Antarctic Circumpolar Current Front: physical and biological coupling at South Georgia. Deep-Sea Res. I, v. 49, p. 2183-2202. 2002 
WARD, P.; WHITEHOUSE, M.; BRANDON, M.; SHREEVE, R.; WOODD-WALKER, R. Mesozooplankton community structure across the Antarctic Circumpolar Current to the north of South Georgia: Southern Ocean. Mar. Biol., v. 143, p. 121130. 2003.

WHITEHOUSE, M. J.; PRIDDLE, J.; TRATHAN, P. N.; BRANDON, M. A. Substantial open-ocean phytoplankton blooms to the north of South Georgia, South Atlantic, during summer 1994. Mar. Ecol. Prog. Ser., v. 140, p. 187-197. 1996.

(Manuscript received 04 September 2009; revised 24 March 2010; accepted 22 June 2010) 